\title{
Web-based Information System Design of Karang Taruna with Design Thinking Method Approach (Case Study: Karang Taruna Haur Galur)
}

\author{
Dikdik Musfar Pribadi ${ }^{1}$, Falaah Abdussalaam ${ }^{2}$, Jaenal Arifin ${ }^{3}$ \\ ${ }^{1,2,3}$ Informatics Management Study Program, Piksi Ganesha Polytechnic \\ (J1. Jend. Gatot Subroto 301, Bandung 40274, Indonesia) \\ e-mail: ${ }^{1}$ dmpribadi@ piksi.ac.id, ${ }^{2}$ falaahabdussalaam@gmail.com, ${ }^{3}$ jaenal.arifin@ @iksi.ac.id
}

\begin{abstract}
Karang Taruna Haur Galur plays an active role in the social welfare of Sukagalih Urban Village. Starting from mobilizing the Youth Unit also empowering UMKMs in Sukagalih Urban Village through the Work Program "Koperasi Serba Usaha". Karang Taruna Haur Galur owns 14 compulsory books, including 12 filling books and 2 manuals. The data organized by Karang Taruna Haur Galur is unstructured and yet to have an integrated database. This resulted in an irregular data storage and is also prone to data redundancies. Generations who have not joined Karang Taruna stated that information about Karang Taruna Haur Galur has not been well distributed. The purpose of this research is to improve the data recording system, media of information that connects Karang Taruna Haur Galur and Sukagalih Urban Village Society, also attracting the youth to join Karang Taruna Haur Galur by designing a web-based information system. This web-based information system uses the design thinking method. The research is conducted using direct observations and interviews to the users, as it will help to acquire information on the user's needs for the required building components. Eventually, Karang Taruna Haur Galur is able organize their data as well as gaining broader insights and engagement.
\end{abstract}

Keywords: Information system, Karang Taruna, web, design thinking, data.

\section{Introduction}

Karang Taruna/youth organization is an organization formed by the community. Karang Taruna comes from, by, and for the younger generation who are oriented towards achieving community social welfare. Karang Taruna serves as a forum for the younger generation to develop their potential. Karang Taruna acts as the frontline to support the implementation of social welfare. Every young generation aged 13 (thirteen) to 45 (forty-five) years automatically becomes a member of the Karang Taruna. The smallest scope of Karang Taruna is at the level of Urban Village or Village. In addition to Village or Urban Village, Karang Taruna level is also at Sub District, District/City, Provincial, and National levels [1].

Haur Galur is a Karang Taruna located at urban village level, namely in Sukagalih Urban Village. In 2018 KTHG (Karang Taruna Haur Galur) won the title of the 2nd best Karang Taruna in West Java Province. There are many Karang Taruna activities that can handle problems, especially helping to alleviate problems during the Covid-19 pandemic, for example, the Suka Belajar. Suka Belajar is an activity that is motivated by the presence of online schools due to the impact of the Covid-19 pandemic. Like it or not, parents must be able to help their children learn, but not all parents are ready to teach their children for one reason or another. Therefore, Suka Belajar is a program that helps children learn with assistance from KTHG members. The next program that is currently in the spotlight is the Koperasi Serba Usaha. This program helps UMKM (business micro, small, and mid) in the Sukagalih area whose sales have declined due to the Covid-19 pandemic. This system makes KTHG members active to help sell UMKM goods in the Sukagalih area through social media.

Karang Taruna Haur Galur has 14 mandatory books, including 12 entry books and 2 manuals. The 12 entry books are Karang Taruna activity books, incoming letters, outgoing 
letters, big cash, petty cash, top management meeting attendance, board meeting attendance, work programs, cooperatives, member data, management data, and inventory. The two guidebooks are profiles of Karang Taruna and the Regulation of the Minister of Social Affairs on Karang Taruna. Apart from that book, Karang Taruna Haur Galur has mandatory data, namely the data for Penyandang Masalah Kesejahteraan Sosial (PMKS)/people with social welfare problem which has now changed its name to Pemerlu Pelayanan Kesejahteraan Sosial (PPKS)/people who need the social welfare service. According to the Ministry of Social Affairs of the Republic of Indonesia, currently there are 26 types of PMKS, including neglected children under five, neglected children, children in conflict with the law, street children, children with disabilities, children who are victims of violence or abuse, children who need special protection, neglected elderly, people with disabilities, prostitutes, homeless people, beggars, scavengers, minority groups, former inmates of Correctional Institutions, people with HIV/AIDS, victims of drug abuse, trafficking victims, victims of violence, migrant workers with social problems, victims of natural disasters, victims of social disasters, socio-economic vulnerable women, the poor, families socio-psychological problems, and remote indigenous communities [2], [3]. However, in Bandung city there are only 25 types due to the absence of remote indigenous community types. In addition to PMKS, there are also Potensi dan Sumber Kesejahteraan Sosial (PSKS)/the potential and social welfare source. PSKS is a person or group that participates in strengthening the implementation of social welfare for the community. There are 12 types of PSKS recorded, including professional social worker, Pekerja Sosial Masyarakat (PSM), Taruna Siaga Bencana (Tagana)/disaster aid corps, Lembaga Kesejahteraan Sosial (LKS)/social welfare foundation, Karang Taruna, Lembaga Konsultasi Kesejahteraan Keluarga (LK3)/family welfare colsultation foundation, pioneer family, Wahana Kesejahteraan Sosial Keluarga Berbasis Masyarakat (WKSBM)/social based welfare media, women social welfare leaders, social educator, Tenaga Kesejahteraan Sosial Kecamatan (TKSM)/subdistrict social welfare force, dan business world [3]. Now TKSM has changed its name to Tenaga Kesejahteraan Sosial Kecamatan (TKSK)/subdistrict social welfare force [4].

Currently, data recording at Karang Taruna Haur Galur is already using a computer, namely using spreadsheet media. However, administrators find it difficult because each record has a different URL address and is prone to data redundancy. Leaked URL addresses are also vulnerable to intruders/data retrieval without permission.

One of the efforts to integrate data in Karang Taruna Haur Galur is to build an information system. This system will make it easier for the administrators of Karang Taruna Haur Galur in processing data and as a media connection between residents of Sukagalih Urban Village and Karang Taruna Haur Galur.

From the results of interviews, researchers can conclude that Karang Taruna Haur Galur can operate computers. Most of them are familiar with digital record keeping such as Microsoft Word and Excel, and even Power Point. This is an opportunity that researchers take to create an information system that can manage mandatory books and data in Karang Taruna Haur Galur.

This research was conducted independently of the results of previous studies as a comparative research tool. Past researcher is very important as the basis research implementation. This research will be guided by various past studies, including:

Sistem Informasi Pengelolaan Kegiatan Karang Taruna (SIPEKATAR) Naralatu Agantuka Berbasis Website [5]. They use Rapid Application Development (RAD) as a software development method. The result of this research is able to manage activity data, management of member data, activity proposal data, news data, meeting results data, funds data, admin data, and photo albums.

[6]. They apply the waterfall process in their design, and they can handle activity data, users, and galleries in the end.[7]. This study employs a responsive web with PHP and HTML programming languages, as well as MySQL for database management. The system that he developed as a result of his research is capable of performing proper data management. [8]. In this study states that computerized cash recording has the right accuracy. The shift from manual recording on paper to automatic recording using a computer has many benefits, including time 
efficiency and cost savings.[9]. From this research, the researchers can conclude that in fact the Indonesian people have been able to walk with technology and need more advanced technology.

From previous research, researchers can conclude that most of them only focus on a few mandatory books. This is very unfortunate because a lot of data from Karang Taruna can be processed digitally. The role of Karang Taruna in society is very important. Because Karang Taruna is one of the parties that support the implementation of social welfare for all Indonesian people. However, the absence of a support system that can manage the complete administrative data of Karang Taruna is a problem that researchers cannot ignore. Therefore, the researchers took steps to build a Karang Taruna information system design based on 14 mandatory books.

The advantage of the Web-based Information System Design of Karang Taruna with Design Thinking Method Approach is an information system that can manage all administrative data of Karang Taruna, namely 14 mandatory books. As well as being able to support the welfare function, namely by providing PPKS, PSKS, and UMKM recording features. Later, from this data, Karang Taruna Haur Galur will be able to monitor residents who need assistance. On the other hand, it opens up opportunities for students or other parties to collaborate with Karang Taruna Haur Galur with the availability of an official website.

In this design, the researchers use the design thinking method because this method is relatively young and up to date, as well as the process that involves users and developers directly. Design thinking is a methodology or framework or a way of thinking, to find certain ways to solve complex problems governed by several principles. Design thinking is like a mindset. Because it adheres to an approach that has a focus on user-based experience. Later that user experience will help developers produce the right output [10].

The web-based Karang Taruna Haur Galur information system was built using the Laravel Framework. Laravel is a MVC (Model, View, Control) PHP web development framework that has a clean syntax and can save implementation time [11]. One of the up-to-date features of Laravel is migration. In this feature the database can be modified easily by the developer. In addition, in Laravel there is a Blade template engine which gives an aesthetic impression and partial code cleanliness in the view section [12]. The database used in this development is MySQL. PHP and MySQL are a pair that can make web apps dynamic and interactive [13].

\section{Research Methods}

In this design, the researchers use a design thinking approach. Design thinking is a usercentered (human-centered) method. So, designers really pay attention to user needs and provide solutions to problems experienced by users. In design thinking there is also an empathy stage where the designer needs to know what the user feels. Design thinking is divided into 5 stages [14].

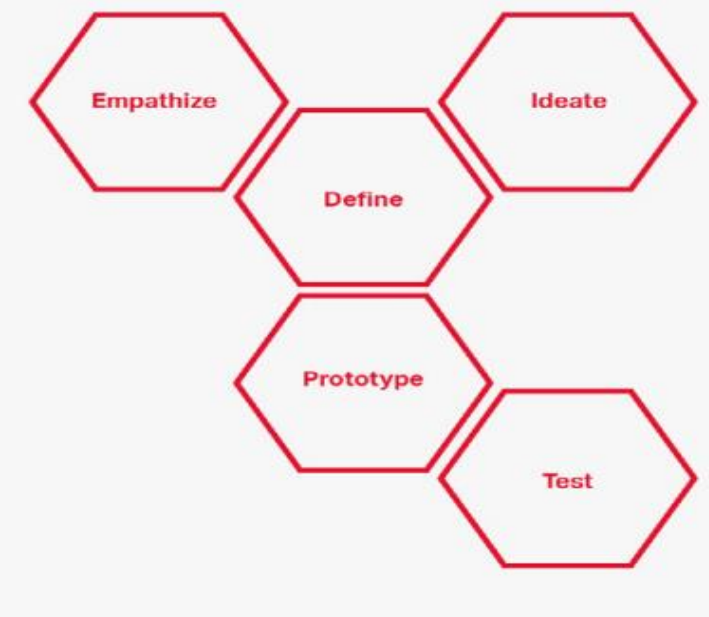

Figure 1. Stanford d.school's design thinking framework. 


\subsection{Empathize}

The essence of design thinking is to focus on empathy. At this stage the designer needs to position himself as a user. What users see and feel. The purpose of this stage is to understand the user's needs, desires, what is the background of such users? What is the thing that annoys users the most? Designers need to know as much as possible about how users perform their activities and how to help them. Most important of this stage is that the designer needs to refrain from making assumptions about the user. One of the steps of this stage is conducting interviews. Because the key to the success of a large company is to talk directly to users [15].

\subsection{Define}

At this stage it is necessary to formulate the problems experienced by the user at the empathy stage. Use all the knowledge gained as a basis for identifying problems. We need to define issues based on user research, while taking into account user needs. Commonly referred to as POV (Point of View), which can help us be in the scope of the problem and the space for innovative solutions [10].

\subsection{Ideate}

This stage is a stage that requires designers to generate as many ideas as possible to solve the problems formulated in the define stage. It's okay to have unrealistic ideas, collect as many as you can. But at the end of this stage, we must choose which idea is the most appropriate to solve the problem experienced by the user [16].

\subsection{Prototype}

This stage is the time to take the most appropriate idea among other ideas into something real. The chosen idea was turned into a low-fidelity prototype to avoid wasting a long time. After creating a low-fidelity prototype, we can upgrade it to a High-fidelity prototype. High fidelity can help us get closer to the final product. A prototype can be a functional replica of a product. With the prototype method, developers and users can interact with each other to find the right system [17].

\subsection{Test}

The design thinking process varies depending on the industry or sector. Sometimes, the testing process is added to the prototyping stage. The most important part of the trial phase is validation. This stage is a moment to double check that we have formulated the problem correctly and that the solutions we provide can help the user [18].

\section{Result and Discussion}

Based on 5 stages of design thinking. Researchers get results which include the following.

\subsection{Empathize}

At this stage the researcher uses the user research method by means of stakeholder interviews. Researchers used the help of Affinity Map to collect knowledge from interviews [19]. Researchers have 3 target users who will be interviewed, the following are the targets and results of the interviews:

\subsubsection{Top management Karang Taruna Haur Galur}

The main target is the top management of Karang Taruna itself. Researchers conducted interviews with the chairman, vice chairman, secretary, and treasurer.

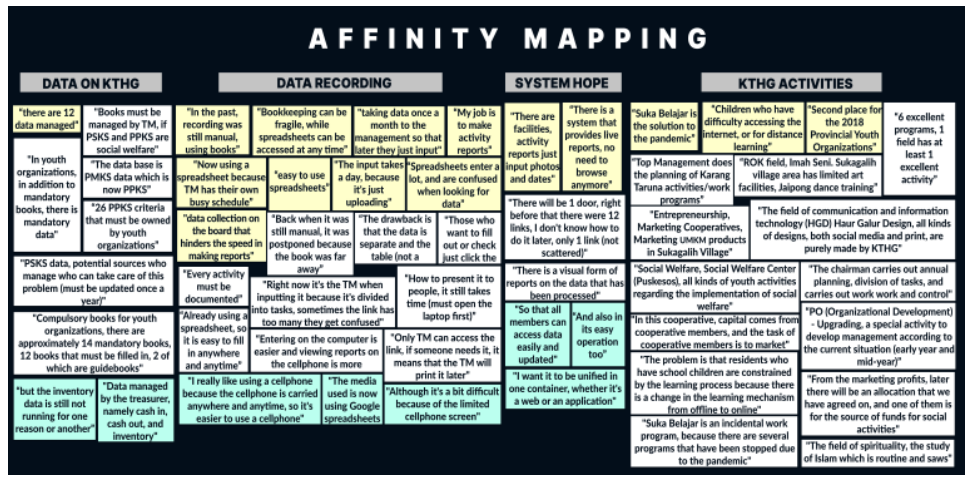

Figure 2. Affinity Map: Top Management KTHG 
3.1.2. The younger generation in Sukagalih Urban Village area who have reached the age of members of Karang Taruna

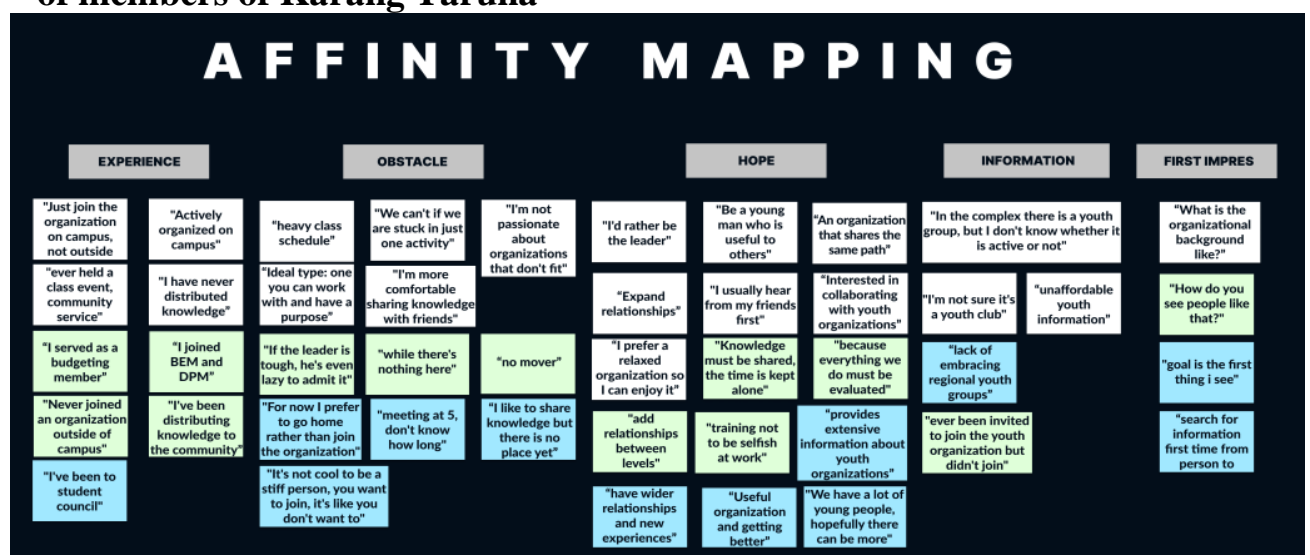

Figure 3. Affinity Map: younger generation Sukagalih Urban Village

Furthermore, the researchers interviewed the younger generation in Sukagalih Urban Village area who had reached the age of Karang Taruna members but were still not active in Karang Taruna activities. The goal is to fill in any content that needs to be provided on the website in order to attract their interest.

\subsubsection{College students who are outside Sukagalih Urban Village}

The last is interviews with college students who are outside Sukagalih Urban Village. The goal is that the content provided later can open up opportunities to collaborate with students with the first media link, namely the website.

\begin{tabular}{|c|c|c|c|c|c|c|c|c|c|c|}
\hline & EXPERIENCE & & OBSTACLE & & HOPE & & & IFORMATIO & & FIRST IMPRES \\
\hline $\begin{array}{c}\text { "Join an } \\
\text { off-campus } \\
\text { organization" }\end{array}$ & \multicolumn{2}{|c|}{ "join student associations" } & $\begin{array}{l}\text { "most people end up feeling } \\
\text { the most in control" }\end{array}$ & $\begin{array}{c}\text { "should be a } \\
\text { better } \\
\text { organization" }\end{array}$ & $\begin{array}{l}\text { "no matter how great it } \\
\text { is if it is not professional } \\
\text { what is it for" }\end{array}$ & $\begin{array}{l}\text { "has a plan to } \\
\text { socialize to to the } \\
\text { community" }\end{array}$ & \multirow{2}{*}{\begin{tabular}{c|} 
"expand \\
socialization \\
about youth \\
organizations \\
here" \\
\end{tabular}} & \multirow{2}{*}{\begin{tabular}{|c|} 
"I believe in \\
youth \\
organizations \\
in this \\
neighborhood" \\
\end{tabular}} & \multirow{2}{*}{$\begin{array}{c}\text { "No friend } \\
\text { has ever } \\
\text { shared } \\
\text { about youth } \\
\text { oroups" }\end{array}$} & \multirow{2}{*}{$\begin{array}{l}\text { "ever heard of youth } \\
\text { organization, } \\
\text { because } 17 \text { august" } \\
\text { "I don't know about } \\
\text { the youth program }\end{array}$} \\
\hline \multirow{4}{*}{\begin{tabular}{c|c} 
"Now I am \\
the head of \\
the KPU's \\
event \\
organizer"
\end{tabular}} & \multirow{4}{*}{$\begin{array}{c}\text { "New work } \\
\text { program is a } \\
\text { new } \\
\text { challenge" }\end{array}$} & & \multirow{2}{*}{\begin{tabular}{c|c}
$\begin{array}{c}\text { science to the } \\
\text { public" }\end{array}$ & $\begin{array}{l}\text { is now with } \\
\text { yourself" }\end{array}$ \\
\end{tabular}} & \multirow{2}{*}{$\begin{array}{c}\text { "be a professional } \\
\text { so you don't get } \\
\text { bored" }\end{array}$} & \begin{tabular}{l|l} 
"ideal type: & "sc \\
hiere must be a & \\
firm leader" & "h
\end{tabular} & $\begin{array}{l}\text { "self-awareness is } \\
\text { the main key" } \\
\text { "has a areat boss" }\end{array}$ & & & & \\
\hline & & \multirow{3}{*}{$\begin{array}{l}\text { "Mostly } \\
\text { every time } \\
\text { I serve I } \\
\text { become a } \\
\text { secretary" }\end{array}$} & & & \multirow{2}{*}{\begin{tabular}{|c|} 
"get a new \\
experience, new \\
knowledge"
\end{tabular}} & \multirow{2}{*}{$\begin{array}{l}\text { "ideal type: who } \\
\text { has good } \\
\text { communication" }\end{array}$} & \multirow{3}{*}{\begin{tabular}{|c|} 
"Lack of youth \\
support \\
because 1 \\
don't have \\
friends" \\
\end{tabular}} & \multirow{2}{*}{$\begin{array}{l}\text { "I entered the } \\
\text { entrepreneurship section, } \\
\text { but it's not clear, you know" }\end{array}$} & \multirow{2}{*}{$\begin{array}{l}\text { L groups" } \\
\text { ed the } \\
\text { hip section, } \\
\text { r, you know" }\end{array}$} & \multirow{3}{*}{$\begin{array}{l}\text { work" } \\
\text { "do not understand } \\
\text { each other's duties } \\
\text { in the youth } \\
\text { organization" }\end{array}$} \\
\hline & & & $\begin{array}{l}\text { "l'mi in college but it's not } \\
\text { useful for other people, what's } \\
\text { that for" }\end{array}$ & \multirow{2}{*}{\begin{tabular}{|c|}
$\begin{array}{c}\text { "embracing each } \\
\text { other is also good } \\
\text { for the organization" }\end{array}$ \\
"interested in \\
sharing knowledge"
\end{tabular}} & & & & & & \\
\hline & & & $\begin{array}{l}\text { "Not everything is handled by } \\
\text { the chairman" }\end{array}$ & & \multirow{2}{*}{\multicolumn{2}{|c|}{\begin{tabular}{|l|} 
"expectations that if you join the \\
organization it will be fun, cool"
\end{tabular}}} & & \multirow{2}{*}{\multicolumn{2}{|c|}{$\begin{array}{l}\text { "I know the youth } \\
\text { organization from Amy's } \\
\text { Instagram" }\end{array}$}} & \\
\hline $\begin{array}{l}\text { "follow student } \\
\text { associations" }\end{array}$ & \multicolumn{2}{|c|}{\begin{tabular}{|c|c|} 
it & "I served as a media \\
bureau"
\end{tabular}} & \begin{tabular}{l|l|}
$\begin{array}{l}\text { T'm a very spacious } \\
\text { person like that" }\end{array}$ & $\begin{array}{l}\text { "lack of } \\
\text { comrades" }\end{array}$ \\
cen
\end{tabular} & \multirow{2}{*}{$\begin{array}{l}\text { "organization as home" } \\
\text { "Iwant a no organization } \\
\text { that is more social" }\end{array}$} & & & \begin{tabular}{|c|}
$\begin{array}{c}\text { "hold more } \\
\text { events" }\end{array}$ \\
\end{tabular} & \multirow{2}{*}{\multicolumn{2}{|c|}{\begin{tabular}{|c|} 
"the role of social media in \\
distributing information is \\
high"
\end{tabular}}} & $\begin{array}{l}\text { "I saw the } \\
\text { members first" }\end{array}$ \\
\hline \multicolumn{2}{|c|}{\begin{tabular}{c|c|} 
"set up website, \\
youtube, and WA hima"
\end{tabular}} & \multirow{3}{*}{$\begin{array}{l}\text { "Never been } \\
\text { in an } \\
\text { organization } \\
\text { at all" }\end{array}$} & \begin{tabular}{|l|l|} 
I really enjoy & "Never share \\
\end{tabular} & & \multicolumn{2}{|c|}{\begin{tabular}{|c|} 
e"|ideal type: useful organization" \\
"n
\end{tabular}} & $\begin{array}{c}\text { "Did I } \\
\text { deserve the }\end{array}$ & & & I used to join the \\
\hline "From middles & school to & & \begin{tabular}{c|c} 
services" & the public" \\
sol
\end{tabular} & "I know the journey & "I hope KTHG " & "solve problems & \begin{tabular}{|l|} 
circle or not? \\
"I once joined
\end{tabular} & "I am motiva & & $\begin{array}{l}\text { youth organization, } \\
\text { I was invited" }\end{array}$ \\
\hline $\begin{array}{l}\text { high school I joi } \\
\text { student cou }\end{array}$ & joined the & & $\begin{array}{l}\text { "I wish there was an } \\
\text { organization focused on soc }\end{array}$ & $\begin{array}{c}\text { of Karang Taruna } \\
\text { Haur Galur" }\end{array}$ & $\begin{array}{l}\text { Pecomes a forum } \\
\text { for society" }\end{array}$ & $\begin{array}{l}\text { that arise in } \\
\text { society" }\end{array}$ & the youth & & & "The youth \\
\hline $\begin{array}{l}\text { "I was vice pre } \\
\text { of student co } \\
\text { junior high sc }\end{array}$ & $\begin{array}{l}\text { resident } \\
\text { ouncil in } \\
\text { school" }\end{array}$ & 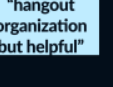 & & $\begin{array}{c}\text { "ideal type: aware } \\
\text { of enviromental } \\
\text { welfare" }\end{array}$ & & & & & & $\begin{array}{l}\text { activities are more } \\
\text { like competitions" }\end{array}$ \\
\hline
\end{tabular}

Figure 4. Affinity Map: College students who are outside Sukagalih Urban Village

\subsection{Define}

In the define stage, the researchers uses the mad-libs technique to convey the results of the analysis. Insight mad-libs are declarative sentences that summarize user needs and interesting insights [18]. The following are the results of the analysis carried out by the researchers from the interview stage.

\subsection{Ideate}

From the insight in the previous stage, the researchers managed to find the right idea With the problems experienced by Karang Taruna Haur Galur, the researchers solved it by creating a web-based information system that integrates data on the Karang Taruna Haur Galur so that there are no more links to record data. And for the other two users, a feature was made on the web that could attract their attention to collaborate or even join Karang Taruna Haur Galur. The following is the system design made by the researchers.

\subsubsection{Data flow in the design of the KTHG information system}

Flowmap can describe the flow and relationships of existing data. At this stage, the researchers make a flowmap that can represent the flow of data in the system because there are 
several identical flows. Later it will be clarified with Data Flow Diagrams (DFD). The flowmaps that the researchers took as representatives include basic data flowmap (gender, education and attendance types), member data flowmap (members and administrators), activity data flowmap (activities and costs), and letter flowmap.

Table 1. Insight Mad-Libs Top management KTHG

\begin{tabular}{cc}
\hline User & Needs \\
\hline $\begin{array}{c}\text { Top management } \\
\text { Garang Taruna Haur who has } \\
\text { implemented a work } \\
\text { program. }\end{array}$ & $\begin{array}{c}\text { Recording/ Documentation/ } \\
\text { Recap of activity results/ } \\
\text { Financial. }\end{array}$ \\
& \\
& \\
$\begin{array}{c}\text { Karang Taruna Haur } \\
\text { Galur is understaffed } \\
\text { to help make the } \\
\text { program for the } \\
\text { welfare of the }\end{array}$ & $\begin{array}{c}\text { Adding external relations } \\
\text { and increasing the interest } \\
\text { of the younger generation } \\
\text { residents successful. }\end{array}$ \\
$\begin{array}{c}\text { in Sukagalih Urban Village } \\
\text { Area to take part in Karang }\end{array}$ \\
Taruna Haur Galur.
\end{tabular}

Users need to record the minutes after the activity is completed because the Karang Taruna has 15 mandatory books, including activities that must be filled in.

I think the recording of the 15 books has been integrated in one medium.

But after talking directly to the customer, I just found out that the records are on different media (many spreadsheet links).

However, there needs to be a system that can integrate all the data owned by Karang Taruna so that it is easy to access and input by the user.

Users need to increase the number of active members in the Karang Taruna

or embrace more members to be active because the Karang Taruna has the principle of gotong royong. And also need to increase the relationship with the younger generation outside the region.

I think the current number of members is enough to run the Karang

Taruna program. But after talking directly to customers, I just found out that there is still a lack of interest in the younger generation to join Karang Taruna.

\begin{tabular}{|c|c|c|}
\hline User & Needs & Insight \\
\hline $\begin{array}{c}\text { The younger } \\
\text { generation in } \\
\text { Sukagalih Urban } \\
\text { Village area who } \\
\text { have reached the } \\
\text { age of members } \\
\text { of Karang } \\
\text { Taruna. }\end{array}$ & $\begin{array}{l}\text { An organization around } \\
\text { the house that can make } \\
\text { itself grow and benefit the } \\
\text { surrounding community. }\end{array}$ & $\begin{array}{l}\text { Users need to get organizational } \\
\text { experience that goes directly to the } \\
\text { community because these activities } \\
\text { can develop themselves. } \\
\text { I think they are aware of the existence } \\
\text { of Karang Taruna Haur Galur in their } \\
\text { area. But after talking directly to } \\
\text { customers, we just found out that they } \\
\text { don't know about the existence or lack } \\
\text { of information about Karang Taruna } \\
\text { Haur Galur and they tend to join } \\
\text { organizations that they know who the } \\
\text { people are or know each other. } \\
\text { However, there needs to be a system }\end{array}$ \\
\hline
\end{tabular}




\begin{tabular}{ccc}
\hline Table 3. Insight Mad-Libs College students outside Sukagalih Urban Village \\
\hline \multicolumn{1}{c}{ Needs } & $\begin{array}{c}\text { that can embrace them so that they } \\
\text { know the existence of Karang Taruna } \\
\text { Haur Galur and can be a medium for } \\
\text { them to develop their potential. }\end{array}$ \\
\hline $\begin{array}{c}\text { User } \\
\text { confused to } \\
\text { distribute the } \\
\text { knowledge } \\
\text { gained on } \\
\text { campus. }\end{array}$ & $\begin{array}{c}\text { Containers/ Facilities to } \\
\text { distribute knowledge. }\end{array}$ & $\begin{array}{c}\text { Users need to channel the knowledge } \\
\text { gained/organized because these } \\
\text { activities can train the user's soft }\end{array}$ \\
skills. \\
I think that when there is an \\
organization on campus, it will be \\
enough for them to share their \\
knowledge. But after talking directly \\
with the customer, we just found out \\
that the lack of embracing the \\
organization to the user/the user's lack \\
of interest in the organization is due to \\
one reason or another. \\
However, there needs to be a \\
facility/container that can be a \\
medium for them to channel their \\
knowledge and at the same time relate
\end{tabular}

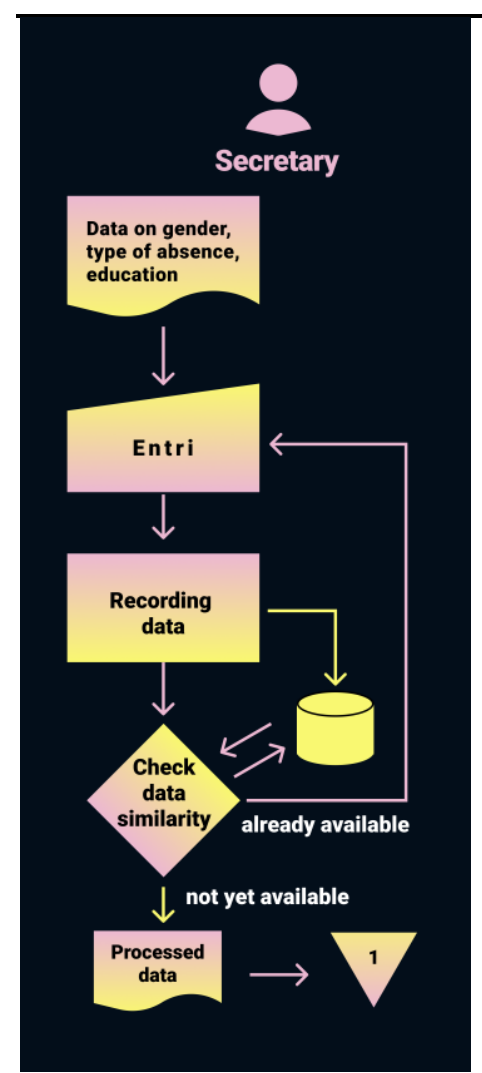

Figure 5. Basic data flowmap

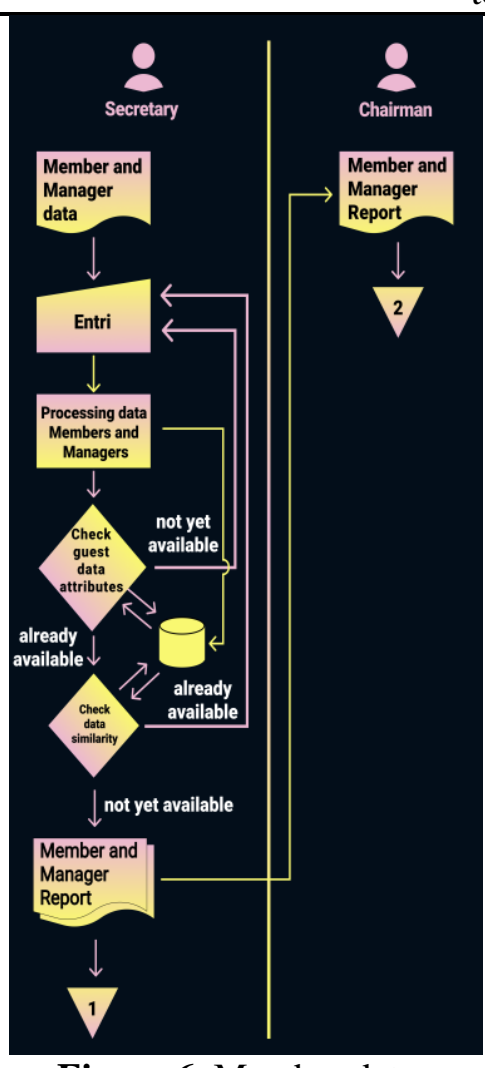

Figure 6. Member data flowmap to the organization.

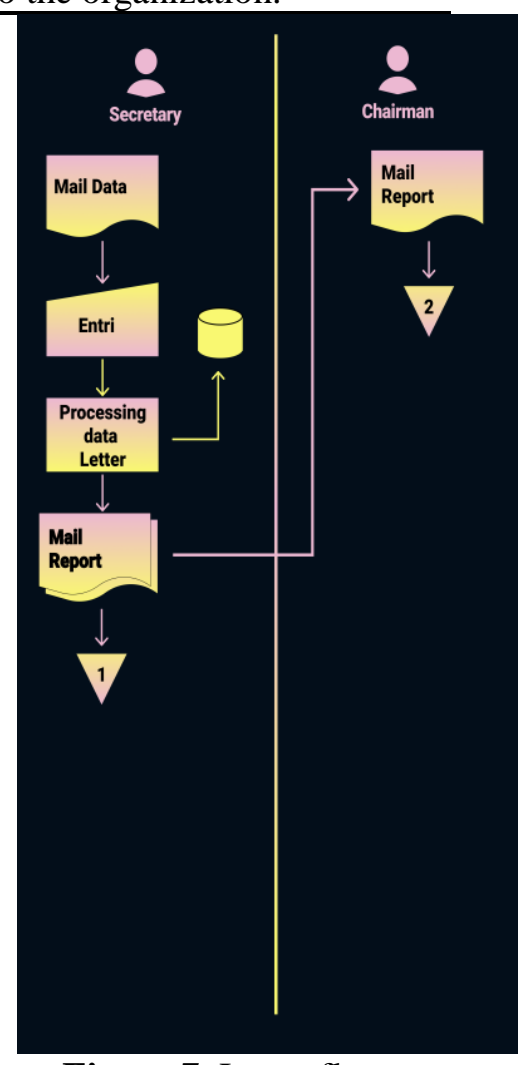

Figure 7. Letter flowmap 


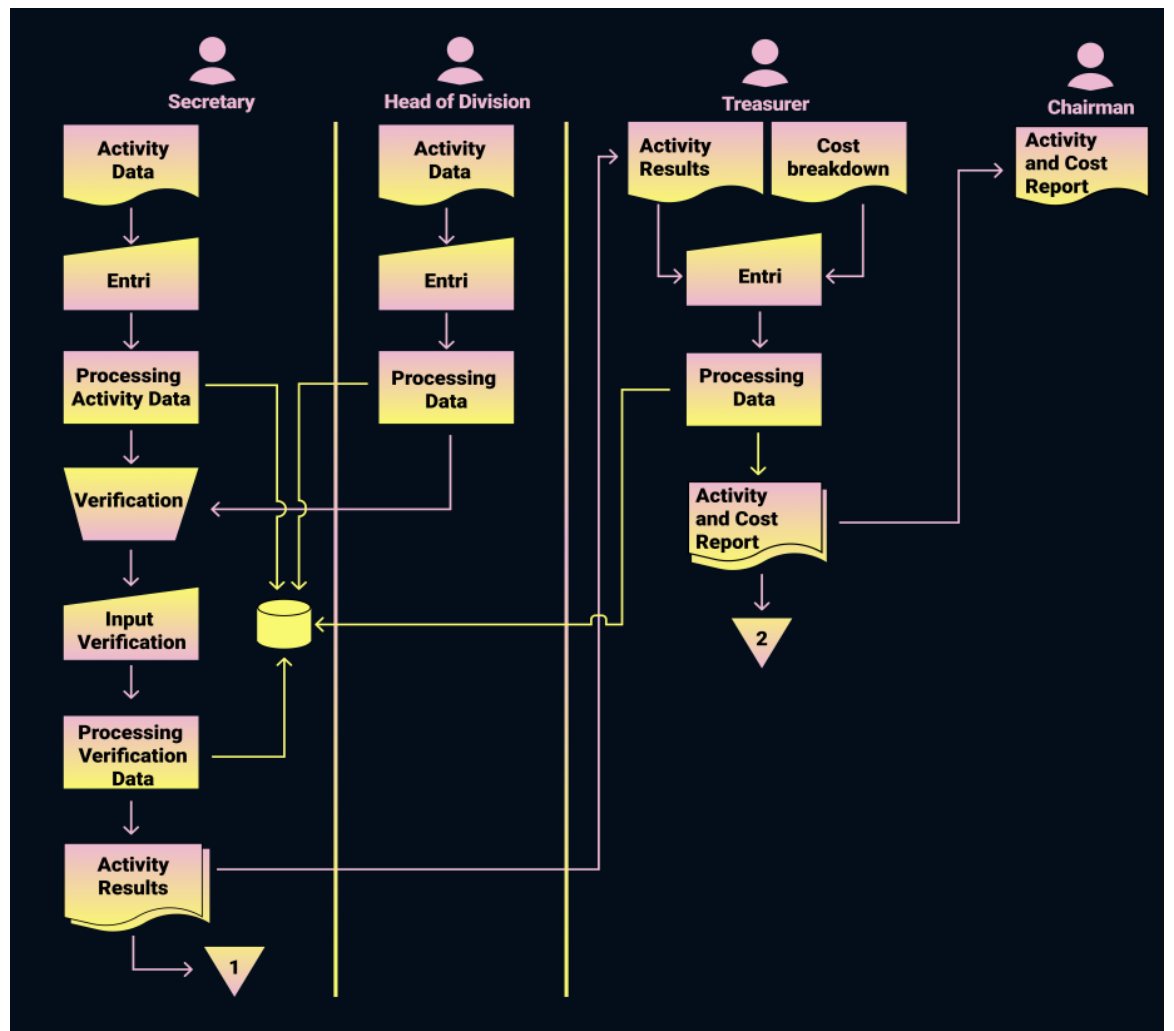

Figure 8. Activity data flowmap

Data Flow Diagram (DFD) is a graphical representation of a system. In this design the researchers makes a DFD to show the flow of data in a system. The highest level of data flow diagrams are context diagrams. This diagram shows the system as a whole [20].

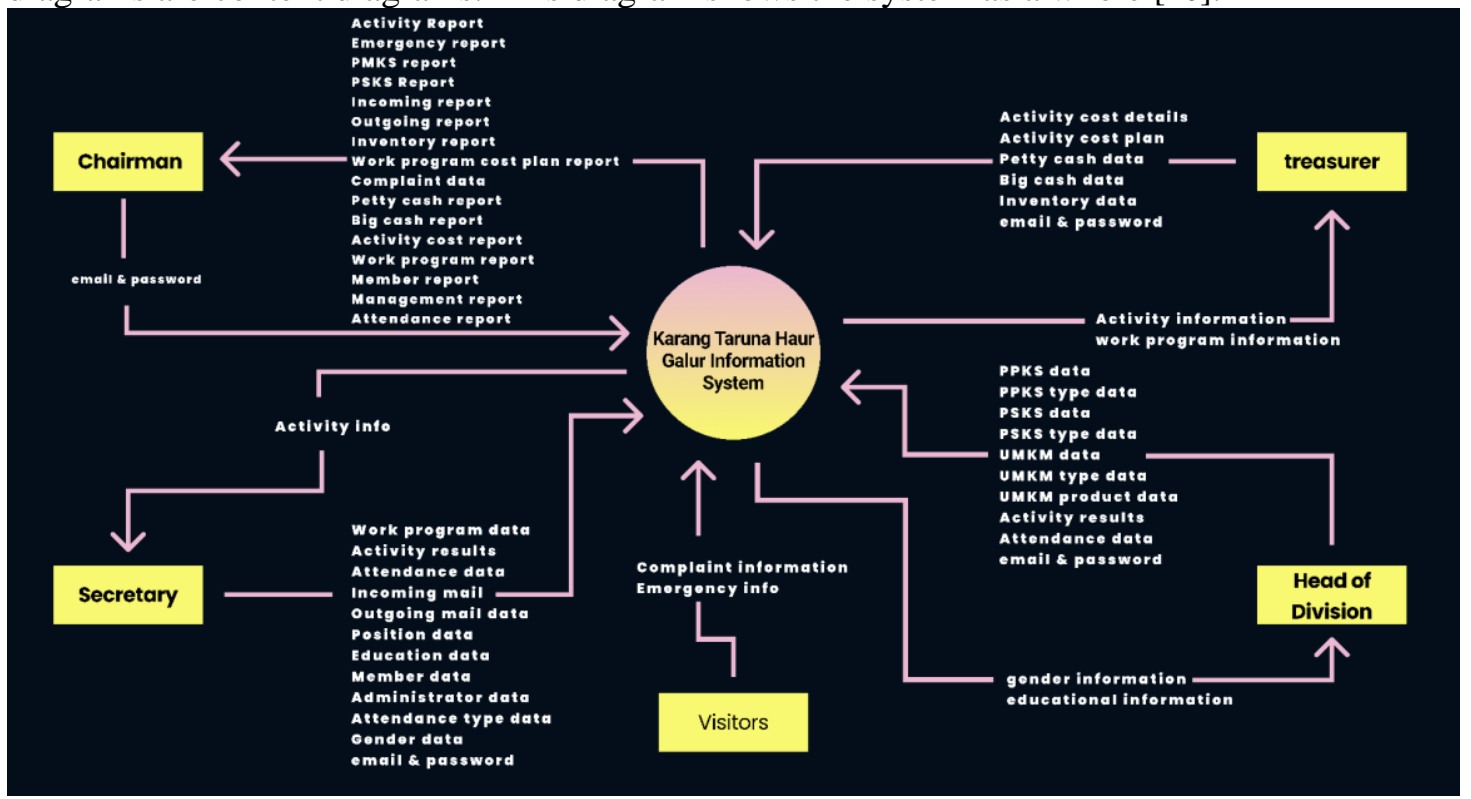

Figure 9. KTHG information system context diagram

From the context diagram above, the results of the fraction become a level 0 diagram (overview diagram).

\subsubsection{Entity Relationship Diagram on KTHG information system design}

Entity Relationship Diagram (ERD) is a network model that shows the relationship between entities stored in the system in an abstract way [21]. 


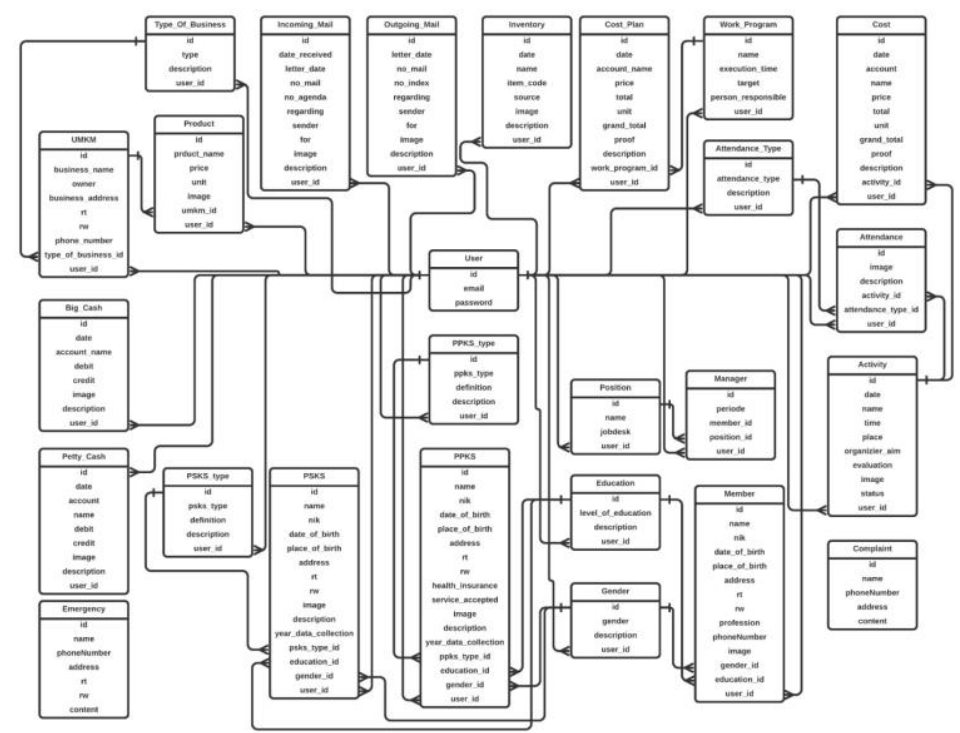

Figure 11. KTHG information system ERD

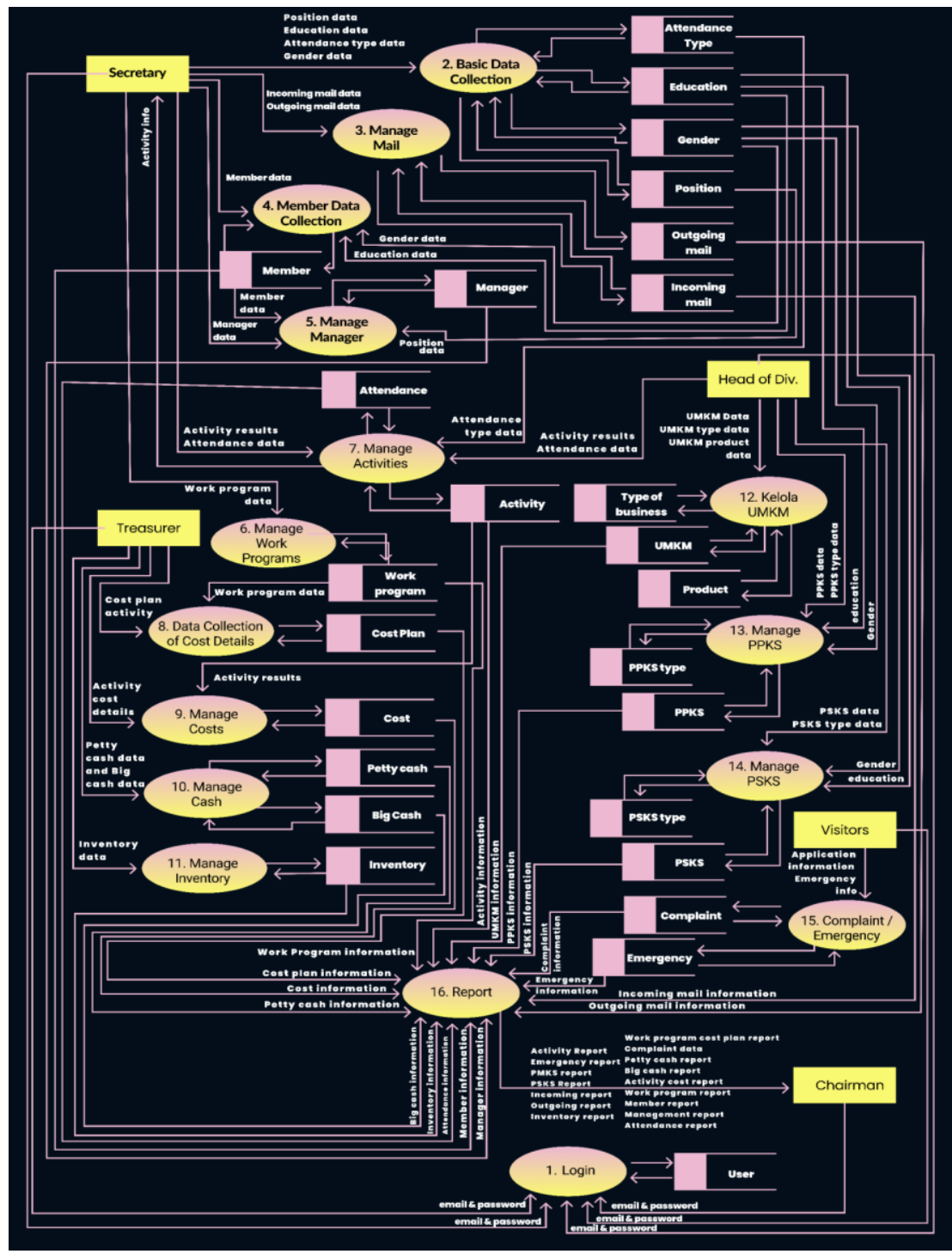

Figure 10. DFD Level 0 KTHG information system 


\subsection{Prototype}

The next stage is making a replication of the system itself. Researchers took the stages of low fidelity and high fidelity because it has effective results [22]. The following is a comparison of the low-fi to high-fi stages of several interface displays.

Table 4. Comparison of Low-fi and High-fi prototypes

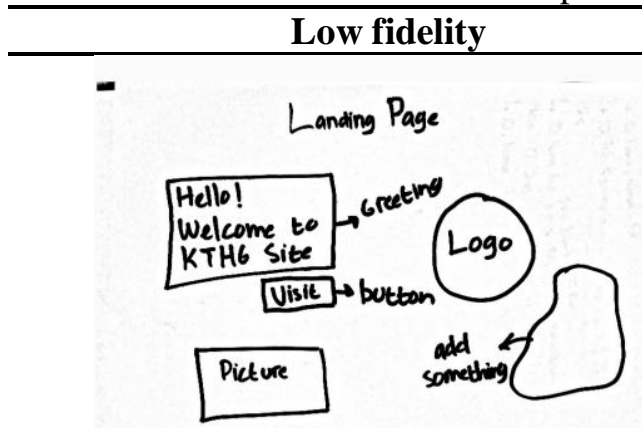

Figure 12. Landing page low-fi

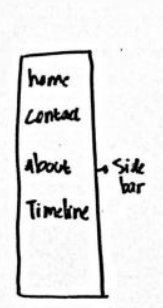

$$
\text { Report Page }
$$
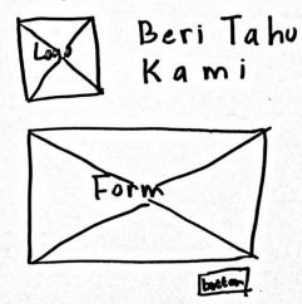

Figure 14. Report page low-fi

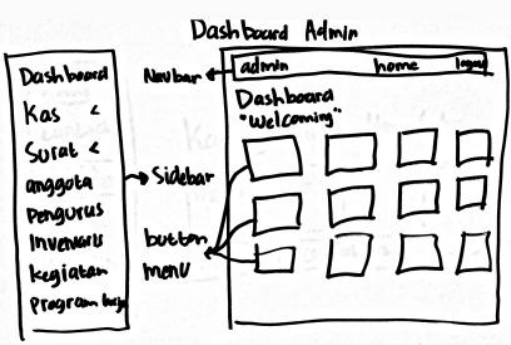

Figure 16. Admin dashboard page low-fi

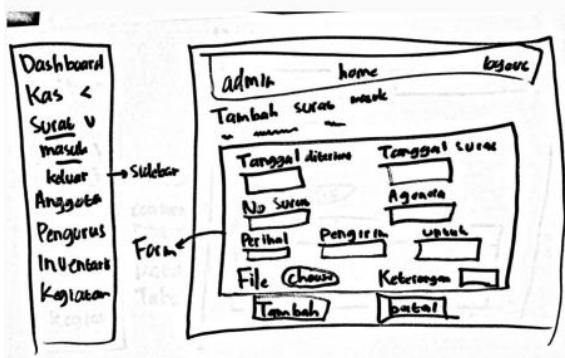

Figure 18. Input form page low-fi
High fidelity

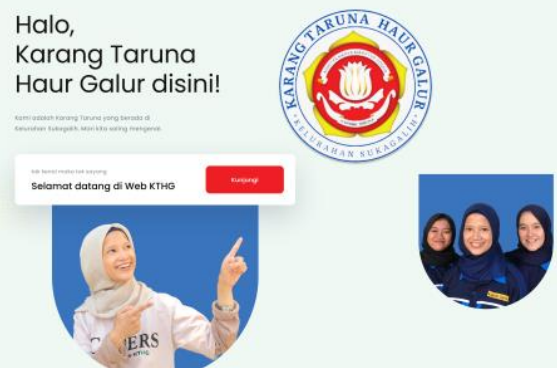

Figure 13. Landing page high-fi

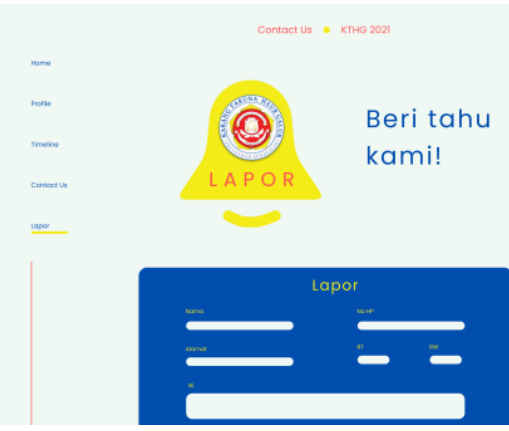

Figure 15. Report page high-fi

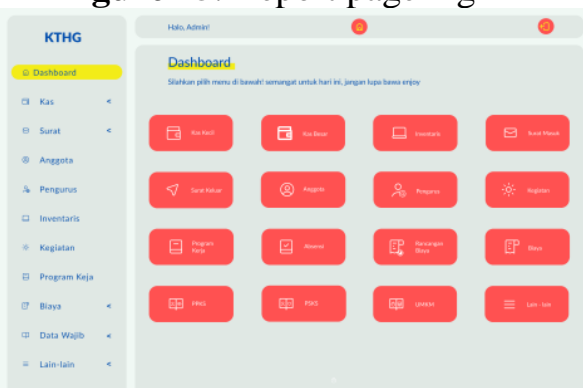

Figure 17. Admin dashboard page high-fi

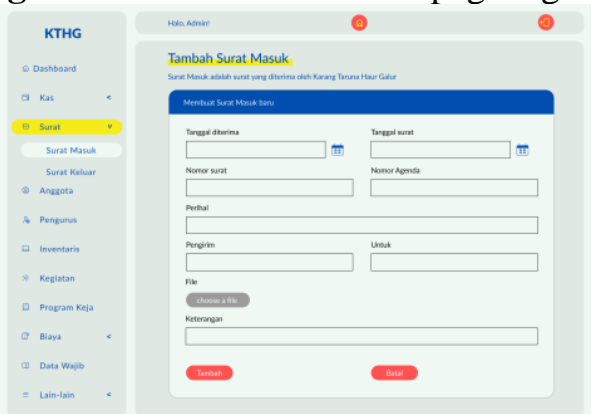

Figure 19. Input form page high-fi 


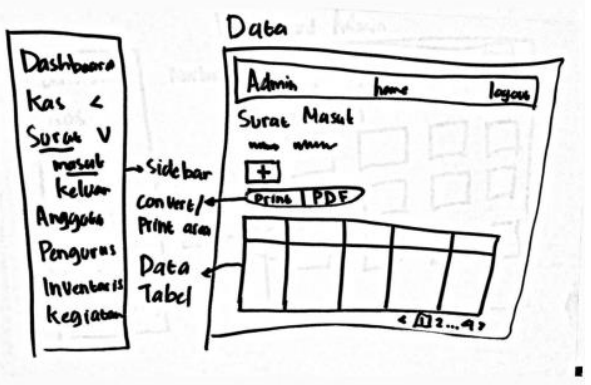

Figure 20. Data page low-fi

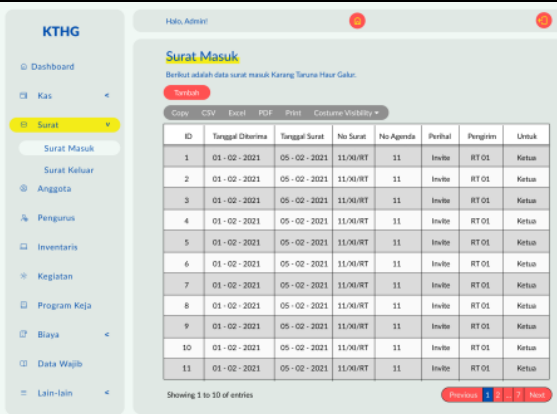

Figure 21. Data page high-fi

\subsection{Test}

At the testing stage, the researcher uses the Black Box Testing method with the Boundary Value Analysis technique because this method can include representatives of the estimated system boundaries [23].

Table 5. Test the system with the black box method

\begin{tabular}{|c|c|c|c|}
\hline Test ID & Description & Expected results & Status \\
\hline BD1 & $\begin{array}{l}\text { Enter all inputs in the PPKS data } \\
\text { column }\end{array}$ & $\begin{array}{l}\text { The system rejects input because } \\
\text { there is no data on gender, type of } \\
\text { PPKS, and education. }\end{array}$ & $\checkmark$ \\
\hline BD2 & $\begin{array}{l}\text { Entering gender and information in } \\
\text { the gender data column }\end{array}$ & $\begin{array}{l}\text { The system successfully receives } \\
\text { data and displays it with a table }\end{array}$ & $\checkmark$ \\
\hline BD3 & $\begin{array}{c}\text { Enter all inputs in the PPKS data } \\
\text { column after successfully filling in } \\
\text { data on gender, type of PPKS and } \\
\text { education }\end{array}$ & $\begin{array}{c}\text { The system can receive data and } \\
\text { display the results in the PPKS data } \\
\text { table }\end{array}$ & $\checkmark$ \\
\hline BD4 & $\begin{array}{l}\text { Empty the NIK column for data } \\
\text { entry in the PSKS column }\end{array}$ & $\begin{array}{l}\text { The system will reject the data and } \\
\text { then return it to the column filling } \\
\text { and tell where the error is }\end{array}$ & $\checkmark$ \\
\hline BD5 & $\begin{array}{c}\text { Displaying complete data details on } \\
\text { one of the data displayed in the } \\
\text { PSKS table }\end{array}$ & $\begin{array}{l}\text { The system will display complete } \\
\text { data from one of the selected data }\end{array}$ & $\checkmark$ \\
\hline BD6 & $\begin{array}{l}\text { Edit data with the "update" button } \\
\text { and replace the data in the PPKS } \\
\text { table }\end{array}$ & $\begin{array}{l}\text { The system will display a form to } \\
\text { correct and can replace the data } \\
\text { according to the edits }\end{array}$ & $\checkmark$ \\
\hline BD7 & $\begin{array}{l}\text { Delete one of the data in the PPKS } \\
\text { table }\end{array}$ & $\begin{array}{l}\text { The system will delete the selected } \\
\text { data }\end{array}$ & $\checkmark$ \\
\hline
\end{tabular}

Black Box Testing was carried out directly by the head of Karang Taruna Haur Galur at Sukagalih Urban Village Office. Table 5 shows that the features on the system can function properly. Everything from buttons to foreign keys that connect tables can function as they should.

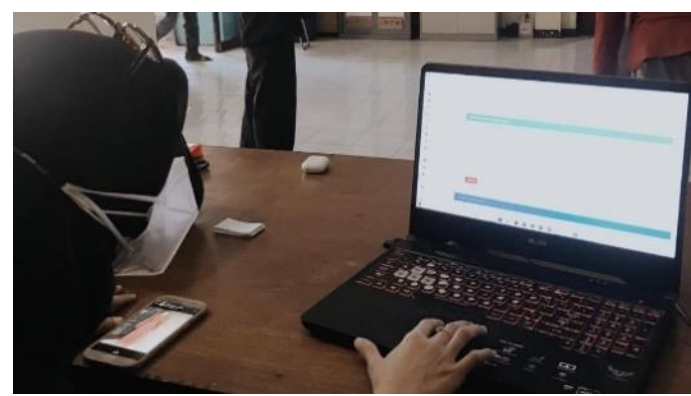

Figure 22. Black Box Testing 
Furthermore, the researchers conducted a trial of the system to 30 respondents, including from inside and outside Karang Taruna Haur Galur. There are 2 assessment indicators, namely the attractiveness of the interface and information on the Karang Taruna Haur Galur website. Researchers use Google Forms to help assess this information system [24].

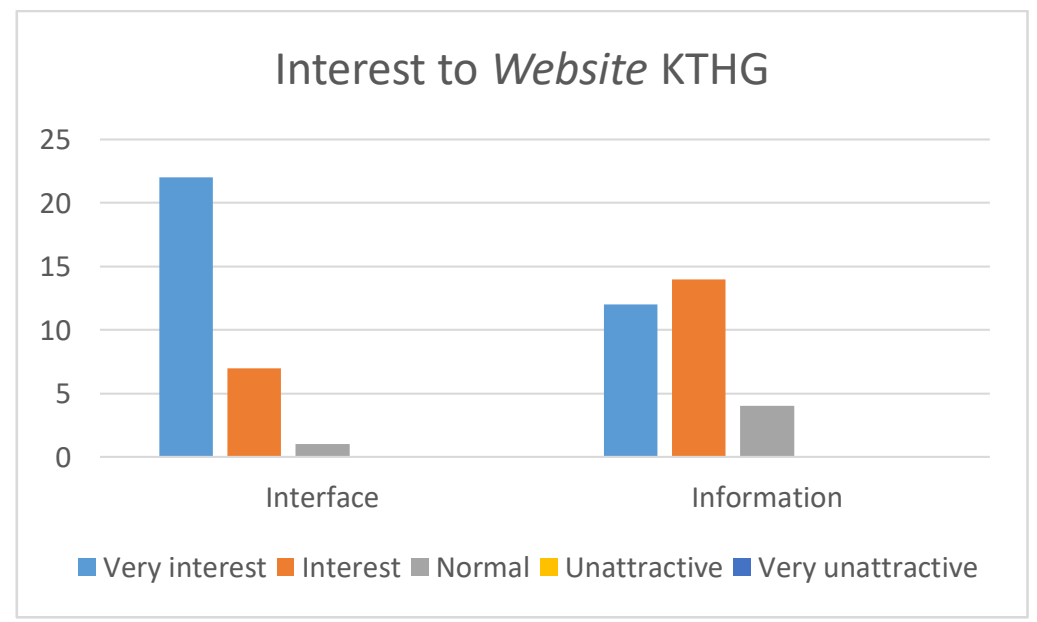

Figure 23. Graph of user interest in the KTHG website

From the graph above, we can see the high appreciation of the users. A total of 14 people feel very interested in the interface, 7 people feel interested, and 3 people feel normal. Then on the indicator of the availability of information on the website, 5 people feel very interested, 12 people feel interested, and 5 people feel normal. Out of 5 scales, there is no user who feels unattractive or very unattractive about this KTHG website.

Researchers can extrapolate from past study that the majority of them only focus on a few mandatory books. This is unfortunate because most of the data from Karang Taruna can be digitally processed. In addition, by offering PPKS, PSKS, and UMKM recording features, the welfare function can be supported. Karang Taruna Haur Galur will be able to track residents who require assistance using this information in the future. The establishment of an official website, on the other hand, opens up options for students or other parties to work with Karang Taruna Haur Galur. The technology owned by this design is more advanced than the previous design. Because it can manage mandatory books and mandatory data completely.

The research method using a design thinking approach makes research results more focused on users. So that researchers can find out what components are needed by users. From the empathy stage, it was found that the information on the existence of Karang Taruna Haur Galur was still minimal. This proves that the existence of a platform to disseminate information is very important. Because the institution of Karang Taruna Haur Galur is already good but it is not yet supported by balanced technology. In this study it was also found that Karang Taruna actually had mandatory books and mandatory data. Both of these things are very beneficial for the high social welfare of the community. The two mandatory data are very influential for the community because Karang Taruna can monitor people who really need help and their development. Researchers hope that in the future, all of Karang Taruna in Indonesia can use this journal as a motivation and reference to build a better one.

\section{Conclusion}

From this design, Karang Taruna Haur Galur can manage its data properly and regularly. 14 books are required to be the basis of accountability for reporting. No need to open many links anymore, just one link is enough, KTHG can report their work.

We can see the enthusiasm of users for the existence of the KTHG website. From the test results, it turns out that there are 2 people who are interested in joining the Karang Taruna Haur 
Galur and are being processed to become active members. This proves that information is important. It must be conveyed in an attractive and equitable manner.

The disadvantages of this system are

- Have not been able to make online attendance which can later make it easier in an activity.

- There is no feature to edit the profile of the website admin

It is hoped that in the future, this system can be developed to cover the current shortcomings. You can also add interesting features, such as making an application on Android to make it easier to access on an Android smartphone.

\section{Bibliography}

[1] Republik Indonesia, "peraturan menteri sosial republik indonesia nomor 25 tahun $2019, " 2019$.

[2] dinas sosial daerah istimewa yogyakarta, panduan pemutakhiran data pmks dan psks tahun 2019. 2019.

[3] republik indonesia, "peraturan menteri sosial republik indonesia nomor 8 tahun 2012," 2012.

[4] republik indonesia, "peraturan menteri sosial republik indonesia nomor 28," 2018.

[5] t. B. P. Regen and p. T. Rapiyanta, "sistem Informasi Pengelolaan Kegiatan Karang Taruna (SIPEKATAR) Naralatu Agantuka Berbasis Website," Prosiding Nasional Rekayasa Teknologi Industri dan Informasi XIV Tahun 2019 (ReTII), 2019.

[6] F. Akbar and S. Setiaji, "rancang bangun sistem informasi karang taruna menggunakan metode waterfall," vol. VIII, no. 1, 2020, [Online]. Available: www.bsi.ac.id

[7] C. Rizki and A. Setiawan, "perancangan sistem informasi event karang taruna ujung menteng cakung," 2020.

[8] H. Jurnal and N. Durahman, "Kas online karang taruna cipasung," jutekin, vol. 6, no. 2, 2018.

[9] R. Febriana Kesuma and L. Halim, Pemanfaatan Sistem Informasi Untuk Pembuatan Laporan Keuangan Karang Taruna Desa Petungsewu. 2020.

[10] E. Woolery, "Design Thinking Handbook," 2019.

[11] B. P. Widodo and H. D. Purnomo, "perancangan aplikasi pencarian layanan kesehatan berbasis html 5 geolocation," jurnal sistem komputer, vol. 6, no. 1, pp. 2087-4685, 2016.

[12] F. Luthfi, "Penggunaan Framework Laravel Dalam Rancang Bangun Modul Back-End Artikel Website Bisnisbisnis.ID," 2017.

[13] W. Istiono, H., and S. "Pengembangan Sistem Aplikasi Penilaian dengan Pendekatan MVC dan Menggunakan Bahasa PHP dengan Framework Codeigniter dan Database MYSQL pada Pahoa College Indonesia," 2016.

[14] S. Doorley, S. Holcomb, P. Klebahn, K. Segovia, and J. Utlet, Design Thinking Bootleg. 2018. Accessed: Jul. 16, 2021.

[15] S. Doody, "starter questions for user research," 2016. Accessed: Jul. 17, 2021. [Online].

[16] R. Costa, "The design thinking proccess for better UX design," Mar. 26, 2019.

[17] A. Andre and H. Dinata, "Interaction Design to Enhance UX of University Timetable Plotting System on Mobile Version," in IOP Conference Series: Materials Science and Engineering, Sep. 2018, vol. 407, no. 1. doi: 10.1088/1757-899X/407/1/012174.

[18] R. Wolniak, "the design thinking method and its stages," 2017.

[19] C. B. Nandita Gupta, "Exploring the Experiences of UX Professionals in Accessibility," The Journal on Technology and Persons with Disabilities, vol. 9, pp. 201-212, 2021,

[20] K. Hapsari and Y. Priyadi, "Perancangan Model Data Flow Diagram Untuk Mengukur Kualitas Website Menggunakan Webqual 4.0," jurnal sistem informasi bisnis, vol. 7, no. 1, p. 66, May 2017, doi: 10.21456/vol7iss1 pp66-72. 
[21] A. Mohammad Kasra Habib, "On the Automated Entity-Relationship and Schema Design by Natural Language Processing," The International Journal of Engineering and Science (IJES), pp. 23-42, 2019, doi: 10.9790/1813-0811034248.

[22] B. Adam, K. Blake, P. Kun, and B. Adam Camburn, "design prototyping of systems," 2017.

[23] D. Ahrizal, M. Khaerul Miftah, R. Kurniawan, and T. Zaelani, "Pengujian Perangkat Lunak Sistem Informasi Peminjaman PlayStation dengan Teknik Boundary Value Analysis Menggunakan Metode Black Box Testing,” vol. 5, no. 1, 2020, [Online].

[24] H. H. Batubara, "Penggunaan google form sebagai alat penilaian kinerja dosen di prodi pgmi uniska muhammad arsyad al banjari," Jurnal Pendidikan Dasar Islam, vol. 8, no. 1,2016 